\title{
Protein-Folding Homeostasis in the Endoplasmic Reticulum and Nutritional Regulation
}

\author{
David Ron and Heather P. Harding \\ Metabolic Research Laboratories, University of Cambridge, and NIHR Cambridge Biomedical Research Centre, \\ Addenbrookes Hospital, Cambridge CB2 0QQ, United Kingdom \\ Correspondence: dr360@medschl.cam.ac.uk
}

The flux of newly synthesized proteins entering the endoplasmic reticulum (ER) is under negative regulation by the ER-localized PKR-like ER kinase (PERK). PERK is activated by unfolded protein stress in the ER lumen and inhibits new protein synthesis by the phosphorylation of translation initiation factor elF $2 \alpha$. This homeostatic mechanism, shared by all animal cells, has proven to be especially important to the well-being of professional secretory cells, notably the endocrine pancreas. PERK, its downstream effectors, and the allied branches of the unfolded protein response intersect broadly with signaling pathways that regulate nutrient assimilation, and ER stress and the response to it have been implicated in the development of the metabolic syndrome accompanying obesity in mammals. Here we review our current understanding of the cell biology underlying these relationships.

Insulin was among the first proteins to be sequenced, among the first to have its structure solved, and therefore among the first to provide clues to the diversity of modifications that affect secreted proteins. The $\beta$ cell of the pancreas, which produces insulin, is one of the best-studied secretory cells, and the role of the secretory pathway in insulin biosynthesis has been recognized from the dawn of modern cell biology. Years later, when the stress pathways that contribute to protein-folding homeostasis in the endoplasmic reticulum (the unfolded protein response, UPR) came under scrutiny (Gardner et al. 2013; Olzmann et al. 2013), it was revealed that their integrity is important to insulin metabolism and to the function of $\beta$ cells.

The precursor of insulin, prepro-insulin, is recruited to the ER membrane cotranslationally through its amino-terminal signal sequence (Mandon et al. 2013). Oxidative folding and signal sequence removal yield mature pro-insulin, whose tertiary structure is stabilized by three disulfide bonds (Bulleid 2012). Folded pro-insulin clears ER quality control (Braakman and Hebert 2013) and traffics distally (Lord et al. 2013).

The peptidase involved in post-ER steps of pro-insulin maturation has long been recognized as playing a key role in its secretion, but the sensitivity of insulin biosynthesis to integrity of ER steps was not recognized until later. An early clue came from study of a naturally occurring mutation in mouse Ins2. The Akita mutation results in a Cys-92 $\rightarrow$ Tyr substitution, disrupting an essential disulfide bond and leading to misfolding of proinsulin 2 (Wang et al. 1999).

Editors: Susan Ferro-Novick, Tom A. Rapoport, and Randy Schekman

Additional Perspectives on The Endoplasmic Reticulum available at www.cshperspectives.org

Copyright (C) 2012 Cold Spring Harbor Laboratory Press; all rights reserved; doi: 10.1101/cshperspect.a013177

Cite this article as Cold Spring Harb Perspect Biol 2012;4:a013177 
Interestingly, a single copy of the mutation is sufficient to compromise $\beta$ cells, whereas homozygosity for a null mutation in Ins2 is without an obvious phenotype in mice (because of redundancy between a rodent's two insulin genes) (Duvillie et al. 1997). The biochemical (and phenotypic) dominance of the Akita mutation in mice (Colombo et al. 2008) fit well with retention of the mutant pro-insulin in the ER, high levels of UPR signaling, and with a progressive decline in $\beta$-cell mass and insulin stores as the mutant mice age. Thus, a perturbation to ER protein-folding homeostasis induced by the misfolding-prone mutant pro-insulin has a long-term negative effect on $\beta$-cell function.

Unbiased human genetics provided an additional clue to the importance of protein-folding homeostasis in the ER; the Wolcott-Rallison syndrome is a rare recessive monogenic form of hypoinsulinaemic neonatal diabetes associated with bone dysplasia and episodic liver failure (Julier and Nicolino 2010). Positional cloning revealed that the causative mutations in EIF2AK3 severely disrupted the expression or function of PERK (Delepine et al. 2000), an ER-localized stress-activated kinase that tunes rates of new protein synthesis to the unfolded protein load in the ER (Harding et al. 1999). Although known to be enriched in $\beta$ cells, PERK expression is ubiquitous (Shi et al. 1998). Therefore, the prominence of diabetes in the phenotype associated with loss-of-function mutations in a ubiquitous component of the unfolded protein response (UPR) pointed to a special role for ER homeostasis in $\beta$-cell health.

More surprising has been the link between chronic ER stress and the ability of insulin target tissues to respond to the hormone; it has emerged that nutrient excess and obesity are associated with higher levels of UPR signaling in the liver and fat and that steps that mitigate ER stress in these tissues ameliorate the insulin resistance that is part of the metabolic syndrome linked to nutrient excess. Thus, ER stress and the response to it affect both the insulin-producing $\beta$ cell and the insulin-responsive tissues and may therefore influence the pathophysiol- ogy of the common, type II form of diabetes mellitus by limiting both the production of insulin and the body's sensitivity to it.

\section{CONTROLLING THE FLUX OF CLIENT PROTEINS INTO THE ANIMAL CELL ER}

In unicellular eukaryotes and plants, the UPR is predominantly a transcriptional program. IRE1, an ER stress sensor that responds to an imbalance between unfolded client protein load and chaperone reserve, activates a downstream transcription factor by an unconventional splicing event (Gardner et al. 2013). Metazoans evolved a translational strand to their UPR, whereby ER stress attenuates new protein synthesis. Thus, the UPR in animal cells is bipartite, with an acute program that attenuates the load on the ER and a more latent transcriptional program-mediated jointly by IRE1, PERK, and ATF6 - that builds ER capacity.

\section{eIF2 $\alpha$ PHOSPHORYLATION-AN ANCIENT MECHANISM FOR REGULATING TRANSLATION}

Translational regulation in the animal cell UPR is achieved by coupling ER stress to the phosphorylation of the $\alpha$-subunit of translation initiation factor $2(\operatorname{eIF} 2 \alpha)$. The key to this innovation is PERK, a type I ER-localized transmembrane protein that fuses a stress-sensing luminal domain that is functionally interchangeable with IRE1, with an eIF2 $\alpha$ kinase cytosolic effector domain that most certainly arose by duplication of an ancestral eIF2 $\alpha$ kinase gene (likely GCN2) (Harding et al. 1999).

The signaling pathway downstream from PERK was already in existence in the unicellular ancestor of animals. Known as the general control response, this signaling pathway comprises eIF2, a translation initiation factor that escorts the charged initiator methionyl-tRNA to the small ribosomal subunit, and, as a ternary complex of eIF2-GTP-tRNA ${ }^{\text {met }}$, contributes to the 43S-ribosomes' ability to recognize AUG start codons and initiate translation (Hinnebusch 2000). AUG codon recognition and formation of the first peptide bond leads to GTP 
hydrolysis. Replenishment of ternary complex pools requires exchange of GDP for GTP on eIF2. This is a highly regulated step, with an exchange factor, eIF2B, and an anti-exchange factor, eIF5. eIF2 $(\alpha \mathrm{P})$, phosphorylated on serine 51 of its $\alpha$-subunit, inhibits the exchange factor eIF2B and thus attenuates the availability of ternary complexes for translation. Because protein synthesis has a major impact on energy and nutrient stores, it is not surprising that signaling by eIF $2 \alpha$ phosphorylation has evolved to influence intermediary metabolism broadly.

Protein-folding homeostasis in the ER benefits from PERK-mediated eIF2 $\alpha$ phosphorylation, because translational attenuation by ER stress contributes to the balance between unfolded proteins entering the ER and chaperone reserve of the compartment. The PERK-mediated translational arm of the UPR gained importance with the rising complexity of the secretory agenda of metazoans. Whereas worms lacking PERK (pek-1) are impaired only after ire-1 deletion (Shen et al. 2001), otherwise wild-type mammalian cells lacking PERK are exquisitely sensitive to ER stress (Harding et al. 2000b).

\section{LOCALIZATION OF PERK ACTION?}

Simple teleological considerations suggest that PERK-mediated translation repression would be restricted to the pool of mRNAs encoding secreted proteins, thereby focusing translation repression on the relevant organelle. PERK location on the ER membrane suggests that this might be readily achieved by restricting the kinase activity to a vicinal pool of eIF2. However, there is no experimental evidence to suggest such selectivity in PERK action and, to date, only global repression has been observed. This may reflect the bluntness of the pharmacological tools used: a comparison of membrane-associated and cytosolic translation in wild-type and PERK knockout cells subjected to agents that promote high levels of ER stress. However, in yeast, eIF2 pools are not segregated, and ternary complex formation presumably entails recycling through a small number of eIF2B clusters (Campbell et al. 2005). The issue of selectivity of PERK action for pools of translating ribosomes thus awaits the development of more refined tools to measure its effects.

\section{eIF2 $(\alpha \mathrm{P})$ DEPHOSPHORYLATION}

In animals, eIF2 $(\alpha \mathrm{P})$ dephosphorylation is performed by two phosphatase complexes. These consist of a common catalytic subunit, PP1, and a regulatory subunit, encoded either by PPP1R15a (GADD34) or PPP1R15b (CReP). The regulatory subunit avidly binds the catalytic PP1 subunit and endows the complex with specificity toward phosphorylated $\operatorname{eIF} 2(\alpha \mathrm{P})$. In mammals, PPP1R15b (the ancestral metazoan protein) is constitutively expressed (Jousse et al. 2003), whereas expression of PPP1R15a, a mammalian invention, is tightly regulated by stress, being induced by conditions that promote eIF $2 \alpha$ phosphorylation. Thus, PPP1R15a contributes to a negative-feedback loop controlling levels of eIF2 $(\mathrm{aP})$ in mammals (Novoa et al. 2001; Brush et al. 2003; Ma and Hendershot 2003; Novoa et al. 2003).

The two regulatory subunits are apparently dedicated to the dephosphorylation of eIF2 $(\alpha \mathrm{P})$, because the early embryonic lethality of their combined deficiency can be completely suppressed by an S51A mutation in eIF $2 \alpha$ $\left(\right.$ Eif2s $1^{\text {tm1Rjk }}$ ), which precludes phosphorylation by upstream kinases (Harding et al. 2009). Lethality of the combined deficiency of PPP1R15 also confirms that levels of phosphorylated eIF $2 \alpha$ are tightly regulated.

Negative feedback at the level of eIF2 $(\alpha \mathrm{P})$ dephosphorylation is mediated by transcriptional control of PPP1R15a, which is mediated by eIF2 $(\alpha \mathrm{P})$. Rare mRNAs are exempt from the global repression of translation because of declining levels of ternary complexes in cells with increasing levels of eIF2 $(\alpha \mathrm{P})$. These include mRNAs encoding the transcription factors ATF4 and ATF5 that are endowed with a peculiar arrangement of upstream open reading frames and are thereby subject to regulated translation reinitiation. This results in repressed translation when ternary complexes are abundant and enhanced translation when their levels decrease. This mechanism, first worked out in yeast 
D. Ron and H.P. Harding

(Hinnebusch 2000), is conserved in its many details in mammalian cells (Lu et al. 2004a; Vattem and Wek 2004; Zhou et al. 2008; Ingolia et al. 2011), and accounts for a substantial fraction of activated gene expression in the unfolded protein response of cultured mouse embryonic fibroblasts (Harding et al. 2003; Lu et al. 2004b).

This eIF2 $(\alpha \mathrm{P})$-dependent gene expression program is not unique to ER stress. Mammals have three additional kinases that phosphorylate eIF $2 \alpha$ in response to other signals. Because it integrates signaling from diverse forms of cellular stress, the pathway has been named the "integrated stress response” (Harding et al. 2003). Its target genes include PPP1R15a, which promotes recovery of protein synthesis following its repression by eIF2 $(\alpha \mathrm{P})$, and genes involved in amino acid import, metabolism, and tRNA charging. Thus, PERK leads to both short-term repression of new protein synthesis-presumably to protect the ER from excessive unfolded protein load-but subsequently promotes the secretory agenda of the cell (Fig. 1). Although these conflicting activities are separated temporally, they contain the seeds of a failure of homeostasis that is considered below.

\section{ER STRESS AND $\beta$ CELLS}

Translational Control in $\beta$ Cells and PERK's Role in Defense of Their Well-Being

Regulating synthesis rates is an important protective mechanism in coping with ER stress

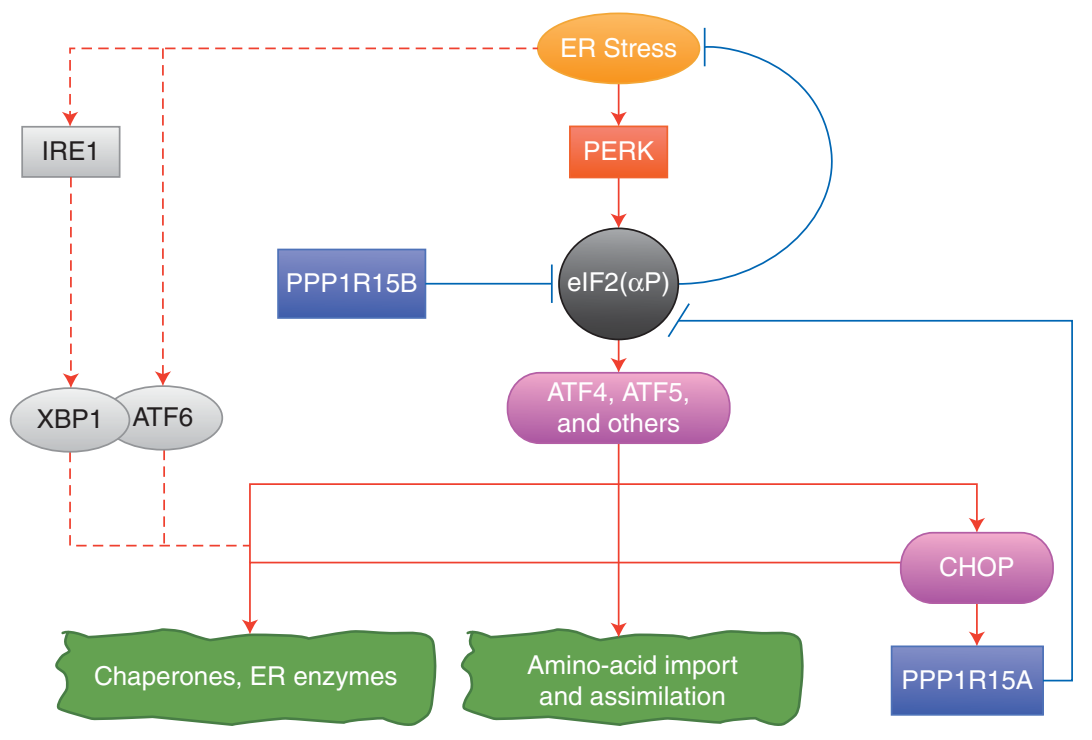

Figure 1. A schematic overview of the eIF2 $\alpha$-phosphorylation-dependent gene-expression program in the context of the UPR. In addition to attenuating global protein synthesis, eIF2 $(\alpha \mathrm{P})$ also up-regulates the translation of rare mRNA, exemplified by those encoding the transcription factors ATF4 and ATF5. This couples increased eIF2 phosphorylation to a gene expression program whose targets include the transcription factor CHOP, which activates a regulatory subunit of an eIF2 $(\alpha \mathrm{P})$-directed phosphatase, PPP1R15A/GADD34, and to enhanced expression of genes involved in amino acid import and assimilation and other more conventional target genes of the UPR that are coregulated by the two other branches of the UPR (IRE1, XBP1, and ATF6). The net effect of this program is to dephosphorylate eIF2 $\alpha$ (a task that is aided by the constitutively expressed PPP1R15B/CReP) and thereby reverse translational repression and to enhance the capacity of the cell to synthesize and secrete proteins by its effects on amino acid metabolism and the ER. The near-immediate repression of protein synthesis upon PERK activation defends the cell against ER stress; however, the gene expression program has conflicting effects on levels of ER stress and appears to have evolved primarily to restore synthesis and secretion of proteins. 
acutely, whereas induced gene expression is important for longer-term adaptation. This is attested to by the hypersensitivity of cultured PERK knockout cells to acute perturbation of the protein-folding environment in the ER (Harding et al. 2000b) and stands in contrast to the relative minor contribution of IRE1 to the resistance of cultured mammalian cells to acute ER stress (Cross et al. 2012).

Theoretical considerations predict that translational control gains importance in circumstances associated with wide fluctuations in client protein load (Trusina et al. 2008). Such fluctuations are substantially restricted to the ER, because cellular growth and developmental programs that unfold gradually dictate protein synthesis in other compartments. In contrast, the ER of a $\beta$ cell may be called upon to accommodate fluctuations of up to 10 -fold in client protein load over a period of $<1 \mathrm{~h}$ (Zucker and Logothetopoulos 1975).

The exuberant increase in pro-insulin translation in response to glycemic excursions occurs despite PERK's moderating influence. The latter accounts for $\sim 30 \%$ less pro-insulin translation observed in glucose-stimulated islets isolated from wild-type mice compared with PERK knockouts (Fig. 2) (Harding et al. 2001b). This moderate difference in client protein synthesis between wild-type and the PERK mutant is nonetheless associated with a progressive decline in $\beta$-cell function and mass, leading to the rapid development of diabetes in mice and humans lacking PERK (Delepine et al. 2000; Harding et al. 2001b; Zhang et al. 2002). However, given that eIF $2 \alpha$ phosphorylation regulates both bulk synthesis of ER client proteins and an important gene expression program (Harding et al. 2003), it has been impossible to date to deconvolute their relative contribution to the phenotype of PERK deficiency. That mice homozygous for an S51A mutation in eIF $2 \alpha$ share the $\beta$-cell defect with the Perk knockout (Scheuner et al. 2001) is unhelpful in regard to this issue, because all of the effects of PERK (transcriptional and translational) are mediated through eIF2( $\alpha$ P) (Lu et al. 2004b). Indeed, some investigators have argued against the primacy of PERK's role in attenuating ER client protein load and have suggested that $\beta$-cell failure in the mutant mice proceeds through the corruption of gene expression programs (Gupta et al. 2010).

In regard to the aforementioned uncertainty, it is worth noting that mutations in known mediators of the eIF2 $(\alpha \mathrm{P})$-dependent gene expression program, the transcription factors ATF4 and CHOP, do not share the $\beta$-cell defect of the PERK knockout; in some circumstances, $\mathrm{CHOP}$ deletion is protective (see below)! However, this argument against the primacy of transcription is weakened by the observation that ATF4 accounts for less than half of the PERKdependent changes in mRNA abundance observed in ER-stressed fibroblasts (Harding et al. 2003). The consequences of PERK deficiency can be ameliorated by inhibition of protein synthesis in cultured cells (Harding et al. 2000b), but this merely indicates that ER stress is a client protein-driven process. IRE1 signaling is enhanced in the tissues of PERK knockout mice (Harding et al. 2001b), but it is impossible to tell if this reflects the loss of a gene expression program that sensitizes cells to physiological levels of client protein load or whether it reflects inappropriately high levels of client protein translation owing to lack of PERK.

The recent availability of potent and selective PERK kinase inhibitors has allowed us to examine, for the first time, the consequences of PERK inactivation in otherwise normal cells subject to physiological levels of ER stress. In fibroblasts, an increase in basal translation is noted within minutes of PERK inactivation. In $\beta$ cells, this is associated with rapid accumulation of high-molecular-weight complexes containing misfolded wild-type pro-insulin. Together, these unpublished observations argue in favor of the importance of translational control in PERK action.

\section{Pathophysiological Mechanisms in ER-Stressed $\beta$ Cells}

$\beta$ cells of the pancreas are sensitive to ER stress and suffer serious consequences from impaired ability to regulate its levels. But how important is ER stress to $\beta$ cells that do not have an overtly 
D. Ron and H.P. Harding

A

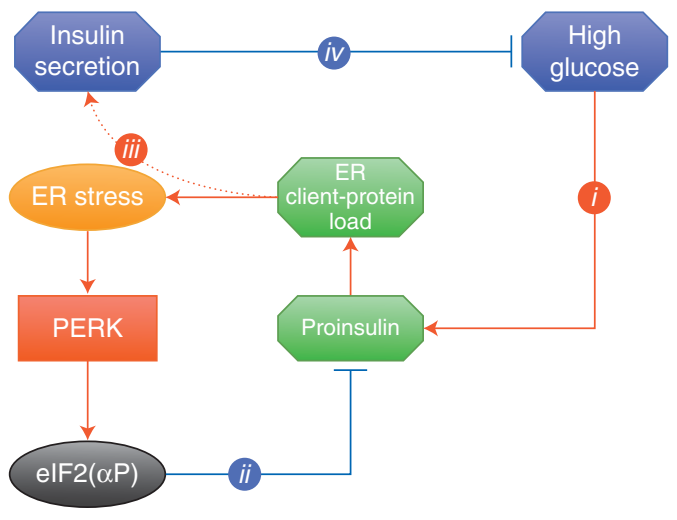

B
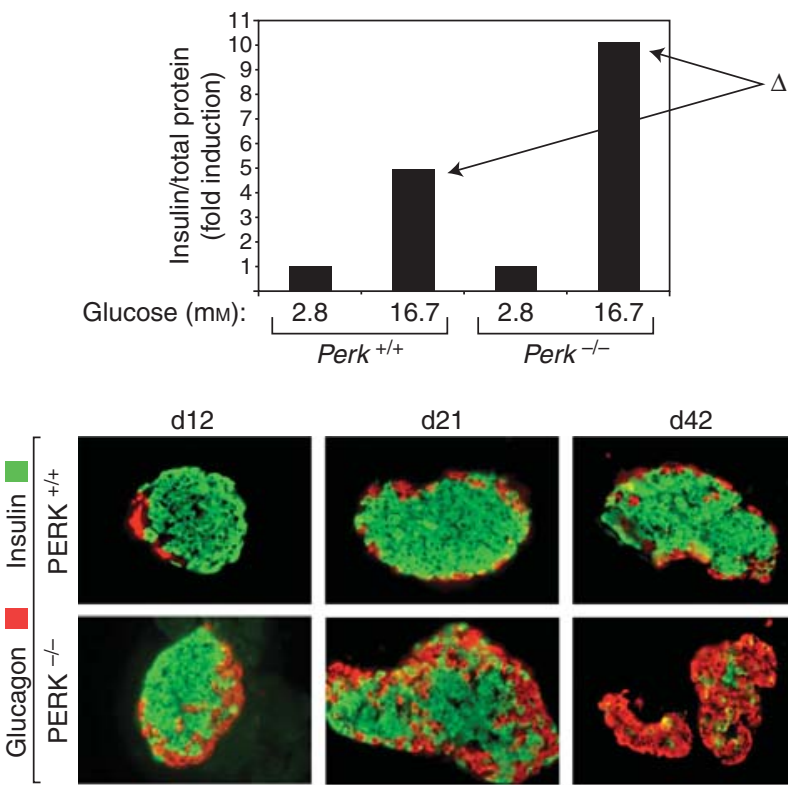

Glucose (mм)
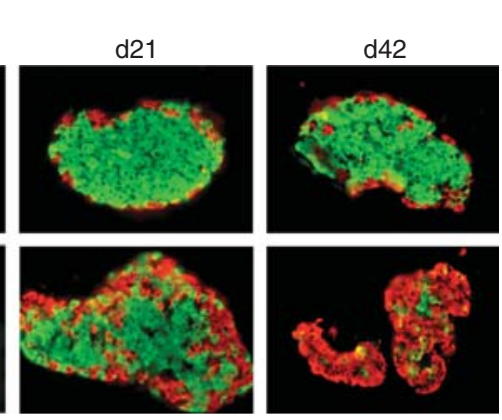

Figure 2. Translational control in $\beta$ cells. (A) Schema of the interplay between glycemic excursions and translational control in $\beta$ cells. High serum glucose $(i)$ stimulates pro-insulin translation in the $\beta$ cell, increasing ER client protein load and promoting a physiological ER stress. The latter is modulated by PERK-mediated eIF $2 \alpha$ phosphorylation (ii), which protects the $\beta$ cell from ER stress while capping insulin synthesis (iii). Insulin resistance, which impairs glycemic control (iv), burdens the $\beta$ cell by increased signaling in $i$. (B) A comparison of the effects of glucose excursions on pro-insulin translation in islets of Langerhans isolated from wild-type and PERK knockout mice. The arrows point to the $\sim 30 \%$ difference $(\Delta)$ in pro-insulin translation affected by PERK signaling (point ii in $A$ ). (C) Photomicrographs of pancreas from wild-type and PERK knockout mice of the indicated age stained with antiserum to insulin and glucagon. Note the profound loss of insulin-positive $\beta$ cells in the PERK mutant. (Panel from Harding et al. 2001a; reprinted, with permission, from the authors.)

compromised UPR or a mutation leading to pro-insulin misfolding? The common adult form of diabetes mellitus (type II) arises in the context of peripheral resistance to insulin action and failure of the $\beta$ cells to keep up with the demand for hormone. Elevated levels of UPR target genes have been noted in the islets of Langerhans of human patients with type II diabetes (Laybutt et al. 2007), suggesting that the overworked $\beta$ cells of individuals with insulin 
resistance may be experiencing more ER stress than those with normal insulin sensitivity.

An excess client protein-driven mechanism for enhanced ER stress is also consistent with experiments in which glucose, a potent driver of insulin biosynthesis, led to higher levels of UPR markers in explanted rodent islets and cultured $\beta$ cells (Wang et al. 2005; Lipson et al. 2006; Elouil et al. 2007). The $\beta$-cell ER's ability to handle client proteins may be further impaired by lipid dysregulation, which prevails in individuals with insulin resistance who often experience hyperlipidemia and have enhanced non-adipose tissue lipid stores. Exposure of cultured $\beta$ cells and islets to excess saturated fatty acids is a potent inducer of UPR signaling (Karaskov et al. 2006). Altered lipid composition of the ER membrane has been shown to lead to dysfunction of the ER calcium pump and promote depletion of lumenal calcium stores. This phenomenon, first observed in macrophages ( $\mathrm{Li}$ et al. 2004), has since been confirmed in $\beta$ cells (Cunha et al. 2008) and liver (Fu et al. 2011).

Given the importance of calcium to the function of diverse ER enzymes and chaperones, it is assumed that lumenal calcium depletion compromises the capacity of the organelle to handle client proteins and activates the UPR via the lumenal stress-sensing domains of IRE1, PERK, and ATF6. However, recent observations in yeast suggest a more complex relationship of lipids to UPR signaling: UPR activation by manipulations that perturb protein-folding homeostasis in the yeast ER lumen requires the lumenal domain of Irelp, as expected. However, a mutant Irelp lacking the lumenal domain can yet recognize perturbation of membrane lipid composition (Promlek et al. 2011). If a similar unconventional mechanism for UPR activation by altered lipid composition exists in mammals, it opens the door to the possibility that lipids tune the UPR independently of their effect on proteinfolding homeostasis in the ER lumen. This seems an important area for future research.

Misfolded mutant pro-insulin (Wang et al. 1999), loss of translational control (Harding et al. 2001a), and lack of ER chaperones (Ladiges et al. 2005) or enzymes (Zito et al. 2010) are all associated with inadequate insulin secretion and reduced $\beta$-cell mass. The theme of unfolded protein load is common to all of these perturbations, but how is it linked to dysfunction of the endocrine pancreas? A large body of research has been devoted to cell death in ER stress. Common downstream cell death effectors are implicated (e.g., see Wei et al. 2001; Cunha et al. 2012), but proximal links remain obscure. It is also difficult to deconvolute the role of cell death from other mechanisms that lead to decline in $\beta$-cell mass. In this regard, it is worth noting that in bone and cartilage, chronic ER stress is associated with transcriptional reprogramming to a less differentiated, less secretory phenotype (Tsang et al. 2007; Murakami et al. 2009). Knockdown of PERK in INS1 cells (a clonal $\beta$-cell line) leads to lower levels of pro-insulin mRNA (Gupta et al. 2010). A similar process in the islets of Langerhans could lead to lower insulin biosynthesis with little or no excess cell death. It is our impression that many plausible pathophysiological mechanisms exist for linking ER stress in $\beta$ cells to islet dysfunction, but their contribution to the pathophysiology of common forms of diabetes mellitus remains to be determined.

Failure of Homeostasis in the ER-Stressed Cell

The $C H O P / D$ dit3 gene is strongly induced via an eIF2 $(\alpha \mathrm{P})$-dependent signaling pathway, which in ER-stressed cells is largely PERK dependent (Harding et al. 2000a). One of the more enduring observations in the field is the survival benefit of CHOP deletion in ER-stressed mammalian cells and tissues (Zinszner et al. 1998). This benefit extends not only to Ins $2^{\text {AKITA }}$ mice confronted with ER stress-mediated $\beta$-cell dysfunction (Oyadomari et al. 2002), but also to $L e p r^{d b / d b}$ mice in which diabetes is induced by a mutation in the leptin receptor gene (Song et al. 2008). Glucose intolerance arises in Lepr $r^{d b / d b}$ mice as a consequence of obesity and insulin resistance. Therefore, the events that unfold in their endocrine pancreas and prevent the organ from matching the demand for insulin are believed to be shared with obese, insulin-resistant humans (the commonplace antecedents of diabetes mellitus in our species). Interestingly, 
CHOP knockout $L e p r^{d b / d b}$ mice have larger islets and more insulin than the $L e p r^{d b / d b}$ mice with intact CHOP. Therefore, the improved glycemic control and enhanced $\beta$-cell mass of the doublemutant mice suggest that ER-stress-mediated CHOP induction in $\beta$ cells may contribute to the pathogenesis of common forms of type II diabetes mellitus.

This is an interesting possibility, but an important limitation applies: The CHOP knockout was global; therefore, it is impossible to exclude that $\mathrm{CHOP}$ action in an insulin-responsive tissue may have contributed to the decline in $\beta$ cell mass and deterioration in glycemic control of the wild-type $L e p r^{d b / d b}$ mice. This is more than a pedantic concern. CHOP antagonizes normal adipogenesis by interfering with the activity of members of the C/EBP family of transcription factors (Ron and Habener 1992; Crozat et al. 1993; Batchvarova et al. 1995). Insulin resistance is believed to develop when the ability to assimilate nutrients in adipose tissue stores is exceeded and lipids begin to accumulate elsewhere (Virtue and Vidal-Puig 2010). By removing a negative regulator of adipogenesis, $\mathrm{CHOP}$ deletion could improve insulin sensitivity and disrupt peripheral feed-forward mechanisms that contribute to islet dysfunction. Indeed, a recent paper reports that $\mathrm{CHOP}$ deletion enhances adiposity while improving insulin sensitivity (Maris et al. 2012). Therefore, it would be informative to compare the effects of nutrient overload in mice with and without a $\beta$-cell-specific knockout of CHOP.

These physiological caveats not withstanding, the evidence that $\mathrm{CHOP}$ contributes cellautonomously to the dysfunction and death of ER-stressed cells is compelling; less so is our understanding of the mechanisms. CHOP overexpression leads to declining glutathione levels and enhanced accumulation of reactive oxygen species (McCullough et al. 2001). CHOP also contributes to the activation of PPP1R15a/ GADD34, the inducible regulatory subunit of the eIF2 $(\alpha \mathrm{P})$-directed phosphatase and to the expression of Ero1L encoding the ER disulfide oxidase ERO1 $\alpha$ (Marciniak et al. 2004). These activities suggest that $\mathrm{CHOP}$ assists its upstream activator ATF4 in preparing the ER-stressed cells to resume secreted protein synthesis, by promoting recovery in ternary complexes, by providing cysteine to fuel protein synthesis, and by enhancing disulfide-bond formation. In the context of severe ER stress, these otherwise homeostatic effects of CHOP are counterproductive. This is reflected in the benefits afforded to severely stressed cells by deletion or inhibition of CHOP or its target GADD34 (Marciniak et al. 2004; Boyce et al. 2005; Tsaytler et al. 2011) and may, in theory, represent a therapeutic opportunity for intervention (Fig. 3).

A

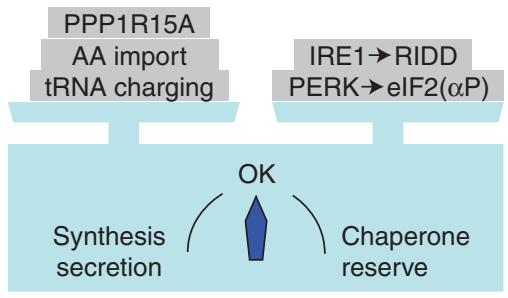

Conventional load

B

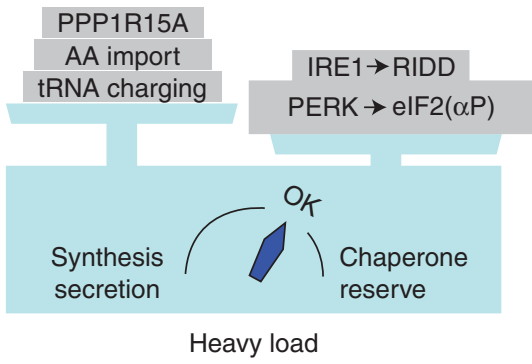

Figure 3. Failure of homeostasis in the UPR. Faced with conventional levels of unfolded protein load $(A)$, homeostasis in the ER lumen is maintained by a balance between factors that favor chaperone reserve by restraining protein synthesis, such as IRE1mediated RIDD and PERK-mediated eIF2 $\alpha$ phosphorylation and factors that favor protein synthesis [such as amino transporters, tRNA synthetases, or eIF2 $(\alpha \mathrm{P})$-phosphatases, PPP1R15A]. This balance was honed by years of natural selection. However, under conditions of usually heavy unfolded protein load, for example, caused by a mutation in an abundant secreted protein such as the Ins $2^{\text {AKITA }}$, homeostasis is favored by a different balance, by one with less PPP1R15A and more eIF2 $(\alpha \mathrm{P})(B)$. This propensity for failure of homeostasis at the UPR's normal set points explains the beneficial effects of PPP1R15A inactivation in certain unusual stressful situations. 
Further evidence for failure of homeostasis in the UPR is provided by the observation that both diminished and excessive eIF2 $(\alpha \mathrm{P})$ contributes to cell dysfunction and death in conditions of severe ER stress (Cnop et al. 2007; Lin et al. 2009). The IRE1 branch of the UPR may also contribute to a failure of homeostasis. Animal cell IRE1 not only is endowed with sequence-specific RNase activity (directed to the mRNA of its effector XBP1), but also possesses the ability to cleave and promote degradation of membrane-bound mRNAs promiscuously (Hollien and Weissman 2006; Hollien et al. 2009). This regulated IRE1-dependent degradation (RIDD) may serve a homeostatic role by contributing to reprogramming the repertoire of mRNAs in stressed cells (Gardner et al. 2013) but when engaged too vigorously may also contribute to decline in $\beta$-cell function (Han et al. 2009; Lee et al. 2011).

We believe that failure of homeostasis deserves careful attention in the apparent switch between the adaptive and maladaptive UPR observed experimentally and that the benefit to organisms from eliminating cells that have experienced ER stress may be minimal. But cells do die and malfunction during ER stress, and regardless of whether this is contributed to by agents that evolved specifically for that purpose or by an imperfect system, understanding the underlying mechanisms may uncover therapeutic opportunities.

\section{ER STRESS IN THE PERIPHERY: INSULIN AND LEPTIN RESISTANCE}

Despite the uncertainties and the gaps in our knowledge, it is easy to countenance a role for ER stress in the insulin-producing $\beta$ cells in the development of type II diabetes mellitus. But the past 8 years have also seen a burgeoning literature linking ER stress and the UPR in peripheral tissues to their ability to respond to insulin and metabolize glucose and other nutrients.

Nutrient excess in the form of a high-fat diet is associated with activation of the UPR in liver and adipose tissue of mice (Ozcan et al. 2004) and man (Gregor et al. 2009). In a longitudinal study of obese humans, UPR markers in liver and fat were initially elevated and then declined with weight loss following bariatric surgery (Gregor et al. 2009). Interestingly, partial compromise of the XBP1 gene, encoding IRE1's effector, markedly enhanced insulin resistance in obese mice (Ozcan et al. 2004), whereas chemical chaperones that are believed to lower the level of ER stress restored insulin sensitivity to obese animals (Ozcan et al. 2006). These earlier studies cited enhanced activation of the Jun amino-terminal kinase (JNK) by hyperactive IRE1 $\alpha$ (Urano et al. 2000) as playing a role in insulin resistance-JNK phosphorylation of the insulin receptor substrate-1 inhibits signaling downstream from its receptor (Ozcan et al. 2004).

The picture has grown more complicated since, and the primacy of JNK activation has been challenged. XBP1 has been reported to inactivate the FOXO1 transcription factor and thereby attenuate the expression of genes involved in hepatic glucose production (Zhou et al. 2011). The eIF2 $(\alpha \mathrm{P})$ branch of the UPR also affects intermediary metabolism. Mice homozygous for the deregulating S51A mutation in Eif2a succumb to neonatal hypoglycemia due to poor accretion of glycogen in the liver at the end of gestation (Scheuner et al. 2001). Adult mice with compromised levels of liver eIF2 $(\alpha \mathrm{P})$ due to a constitutively expressed PPP1R15a transgene also have abnormally low liver glycogen stores and low levels of blood sugar (Oyadomari et al. 2008). Thus, in the liver, the IRE1 and PERK arms of the UPR are pulling in different directions. The outcome of this tugging is influenced further by the non-cell-autonomous effects of these effectors (e.g., see Birkenfeld et al. 2011).

Leptin is a hormone produced by adipocytes that contributes to a negative-feedback loop that suppresses food intake when nutrient stores are replete. Rodent models of obesity recapitulate the physiological resistance to circulating leptin that is observed in most obese humans. Interestingly, in obese leptin-resistant mice, enhanced UPR activity has been measured in the hypothalamic nuclei involved in the neural circuitry by which leptin normally represses appetite (Zhang et al. 2008; Ozcan et al. 2009). The proximate cause of UPR 
hyperactivity in leptin's target cells is unclear as are the mechanisms by which it might link to leptin resistance. Nonetheless, it will be interesting to learn if the two events are linked causally.

Several of the UPR signal transducers evolved from ancestors that were dedicated to metabolic regulation. PERK and its downstream effector ATF4 are likely descendants from GCN2 and GCN4, which regulate amino acid sufficiency in unicellular eukaryotes. ATF6 is a distant cousin of the sterol regulated transcription factor SREBP (Ye et al. 2000). Therefore, it is no surprise that UPR activity affects intermediary metabolism. The difficulty lies in determining the importance of such links. Chemical chaperones that suppress UPR signaling and restore insulin and leptin sensitivity have been cited as evidence in support of the primacy of the link; however, the mechanism of action of these compounds is far from clear, and there is a concern that they are a somewhat blunt tool to dissect a complex problem.

\section{CONCLUDING REMARKS}

Protein-folding homeostasis in the ER is precarious. Secretion is ubiquitous, and the flux of protein into the ER is highly dynamic. Thus, ER stress is a normal feature of life, and the response to it can affect nutritional regulation at multiple levels. The most coherent link is at the level of the pancreatic $\beta$ cell, which produces insulin, but enhanced ER stress in the insulinresponsive tissues also has the potential to affect metabolism. The complex regulation of nutrient acquisition and assimilation has made it difficult to assess the quantitative significance of ER stress and the response to it in metabolic dysregulation. This research effort will benefit from establishing in further detail the components of the UPR and the fundamentals of their activity and then applying that knowledge to complex physiological circumstances.

\section{ACKNOWLEDGMENTS}

This work is supported by a Wellcome Trust Principal Research Fellowship to D.R. and by EU FP7 BetaBat grant 277713 and by NIH grant DK47119.

\section{REFERENCES}

* Reference is also in this collection.

Batchvarova N, Wang X-Z, Ron D. 1995. Inhibition of adipogenesis by the stress-induced protein $\mathrm{CHOP}$ (GADD153). EMBO J 14: 4654-4661.

Birkenfeld AL, Lee HY, Majumdar S, Jurczak MJ, Camporez JP, Jornayvaz FR, Frederick DW, Guigni B, Kahn M, Zhang D, et al. 2011. Influence of the hepatic eukaryotic initiation factor $2 \alpha(\mathrm{eIF} 2 \alpha)$ endoplasmic reticulum (ER) stress response pathway on insulin-mediated ER stress and hepatic and peripheral glucose metabolism. J Biol Chem 286: 36163-36170.

Boyce M, Bryant KF, Jousse C, Long K, Harding HP, Scheuner D, Kaufman RJ, Ma D, Coen D, Ron D, et al. 2005. A selective inhibitor of eIF2a dephosphorylation protects cells from ER stress. Science 307: 935-939.

* Braakman I, Hebert DN. 2013. Protein folding in the endoplasmic reticulum. Cold Spring Harb Perspect Biol doi: 10.1101/cshperpsect.a013201.

Brush MH, Weiser DC, Shenolikar S. 2003. Growth arrest and DNA damage-inducible protein GADD34 targets protein phosphatase $1 \alpha$ to the endoplasmic reticulum and promotes dephosphorylation of the $\alpha$ subunit of eukaryotic translation initiation factor 2. $\mathrm{Mol}$ Cell Biol 23: $1292-1303$.

* Bulleid NJ. 2012. Disulfide bond formation in the mammalian endoplasmic reticulum. Cold Spring Harb Perspect Biol 4: a013219.

Campbell SG, Hoyle NP, Ashe MP. 2005. Dynamic cycling of eIF2 through a large eIF2B-containing cytoplasmic body: Implications for translation control. J Cell Biol 170: 925-934.

Cnop M, Ladriere L, Hekerman P, Ortis F, Cardozo AK, Dogusan Z, Flamez D, Boyce M, Yuan J, Eizirik DL. 2007. Selective inhibition of eukaryotic translation initiation factor $2 \alpha$ dephosphorylation potentiates fatty acidinduced endoplasmic reticulum stress and causes pancreatic $\beta$-cell dysfunction and apoptosis. J Biol Chem 282: 3989-3997.

Colombo C, Porzio O, Liu M, Massa O, Vasta M, Salardi S, Beccaria L, Monciotti C, Toni S, Pedersen O, et al. 2008. Seven mutations in the human insulin gene linked to permanent neonatal/infancy-onset diabetes mellitus. J Clin Invest 118: 2148-2156.

Cross BC, Bond PJ, Sadowski PG, Jha BK, Zak J, Goodman JM, Silverman RH, Neubert TA, Baxendale IR, Ron D, et al. 2012. The molecular basis for selective inhibition of unconventional mRNA splicing by an IRE1-binding small molecule. Proc Natl Acad Sci 109: E869-E878.

Crozat AY, Åman P, Mandahl N, Ron D. 1993. Fusion of CHOP to a novel RNA-binding protein in human myxoid liposarcoma with $\mathrm{t}(12 ; 16)(\mathrm{q} 13 ; \mathrm{p} 11)$. Nature 363: 640-644.

Cunha DA, Hekerman P, Ladriere L, Bazarra-Castro A Ortis F, Wakeham MC, Moore F, Rasschaert J, Cardozo AK, Bellomo E, et al. 2008. Initiation and execution of lipotoxic ER stress in pancreatic $\beta$-cells. J Cell Sci 121: 2308-2318.

Cunha DA, Igoillo-Esteve M, Gurzov EN, Germano CM, Naamane N, Marhfour I, Fukaya M, Vanderwinden 
J-M, Gysemans C, Mathieu C, et al. 2012. Death protein 5 and p53-upregulated modulator of apoptosis mediate the endoplasmic reticulum stress-mitochondrial dialog triggering lipotoxic rodent and human $\beta$-cell apoptosis. Diabetes doi: $10.2337 / \mathrm{db} 12-0123$.

Delepine $\mathrm{M}$, Nicolino $\mathrm{M}$, Barrett T, Golamaully $\mathrm{M}$, Lathrop GM, Julier C. 2000. EIF2AK3, encoding translation initiation factor $2-\alpha$ kinase 3 , is mutated in patients with Wolcott-Rallison syndrome. Nat Genet 25: 406409.

Duvillie B, Cordonnier N, Deltour L, Dandoy-Dron F, Itier JM, Monthioux E, Jami J, Joshi RL, Bucchini D. 1997. Phenotypic alterations in insulin-deficient mutant mice. Proc Natl Acad Sci 94: 5137-5140.

Elouil H, Bensellam M, Guiot Y, Vander Mierde D, Pascal SM, Schuit FC, Jonas JC. 2007. Acute nutrient regulation of the unfolded protein response and integrated stress response in cultured rat pancreatic islets. Diabetologia 50: 1442-1452.

Fu S, Yang L, Li P, Hofmann O, Dicker L, Hide W, Lin X, Watkins SM, Ivanov AR, Hotamisligil GS. 2011. Aberrant lipid metabolism disrupts calcium homeostasis causing liver endoplasmic reticulum stress in obesity. Nature 473: $528-531$.

* Gardner BM, Pincus D, Gotthardt K, Gallagher CM, Walter P. 2013. Endoplasmic reticulum stress sensing in the unfolded protein response. Cold Spring Harb Perspect Biol doi: 10.1101/cshperspect.a013169.

Gregor MF, Yang L, Fabbrini E, Mohammed BS, Eagon JC, Hotamisligil GS, Klein S. 2009. Endoplasmic reticulum stress is reduced in tissues of obese subjects after weight loss. Diabetes 58: 693-700.

Gupta S, McGrath B, Cavener DR. 2010. PERK (EIF2AK3) regulates proinsulin trafficking and quality control in the secretory pathway. Diabetes 59: 1937-1947.

Han D, Lerner AG, Vande Walle L, Upton JP, Xu W, Hagen A, Backes BJ, Oakes SA, Papa FR. 2009. IRE1 $\alpha$ kinase activation modes control alternate endoribonuclease outputs to determine divergent cell fates. Cell 138: 562-575.

Harding H, Zhang Y, Ron D. 1999. Translation and protein folding are coupled by an endoplasmic reticulum resident kinase. Nature 397: 271-274.

Harding H, Novoa I, Zhang Y, Zeng H, Wek RC, Schapira M, Ron D. 2000a. Regulated translation initiation controls stress-induced gene expression in mammalian cells. Mol Cell 6: 1099-1108.

Harding H, Zhang Y, Bertolotti A, Zeng H, Ron D. 2000b. Perk is essential for translational regulation and cell survival during the unfolded protein response. Mol Cell 5: 897-904.

Harding H, Zeng H, Zhang Y, Jungreis R, Chung P, Plesken H, Sabatini D, Ron D. 2001a. Diabetes mellitus and exocrine pancreatic dysfunction in Perk ${ }^{-/-}$mice reveals a role for translational control in survival of secretory cells. Mol Cell 7: 1153-1163.

Harding HP, Novoa I, Bertolotti A, Zeng H, Zhang A, Urano F, Jousse C, Ron D. 2001b. Translational regulation in the cellular response to biosynthetic load on the endoplasmic reticulum. Cold Spring Harb Symp Quant Biol 66: $499-508$.

Harding H, Zhang Y, Zeng H, Novoa I, Lu P, Calfon M, Sadri N, Yun C, Popko B, Paules R, et al. 2003. An inte- grated stress response regulates amino acid metabolism and resistance to oxidative stress. Mol Cell 11: 619-633.

Harding HP, Zhang Y, Scheuner D, Chen JJ, Kaufman RJ, Ron D. 2009. Ppp1r15 gene knockout reveals an essential role for translation initiation factor $2 \alpha$ (eIF2 $\alpha$ ) dephosphorylation in mammalian development. Proc Natl Acad Sci 106: 1832-1837.

Hinnebusch AG. 2000. Mechanism and regulation of initiator methionyl-tRNA binding to ribosomes. In Translational control of gene expression (ed. Sonenberg N, et al.), pp. 185-243. Cold Spring Harbor Laboratory Press, Cold Spring Harbor, NY.

Hollien J, Weissman JS. 2006. Decay of endoplasmic reticulum-localized mRNAs during the unfolded protein response. Science 313: 104-107.

Hollien J, Lin JH, Li H, Stevens N, Walter P, Weissman JS. 2009. Regulated Ire1-dependent decay of messenger RNAs in mammalian cells. J Cell Biol 186: 323-331.

Ingolia NT, Lareau LF, Weissman JS. 2011. Ribosome profiling of mouse embryonic stem cells reveals the complexity and dynamics of mammalian proteomes. Cell 147: 789-802.

Jousse C, Oyadomari S, Novoa I, Lu PD, Zhang Y, Harding HP, Ron D. 2003. Inhibition of a constitutive translation initiation factor 2a phosphatase, CReP, promotes survival of stressed cells. J Cell Biol 163: 767-775.

Julier C, Nicolino M. 2010. Wolcott-Rallison syndrome. Orphanet J Rare Dis 5: 29.

Karaskov E, Scott C, Zhang L, Teodoro T, Ravazzola M, Volchuk A. 2006. Chronic palmitate but not oleate exposure induces endoplasmic reticulum stress, which may contribute to INS-1 pancreatic $\beta$-cell apoptosis. Endocrinology 147: 3398-3407.

Ladiges WC, Knoblaugh SE, Morton JF, Korth MJ, Sopher BL, Baskin CR, MacAuley A, Goodman AG, LeBoeuf RC, Katze MG. 2005. Pancreatic $\beta$-cell failure and diabetes in mice with a deletion mutation of the endoplasmic reticulum molecular chaperone gene P58IPK. Diabetes 54: 1074-1081.

Laybutt DR, Preston AM, Akerfeldt MC, Kench JG, Busch AK, Biankin AV, Biden TJ. 2007. Endoplasmic reticulum stress contributes to $\beta$ cell apoptosis in type 2 diabetes. Diabetologia 50: 752-763.

Lee AH, Heidtman K, Hotamisligil GS, Glimcher LH. 2011. Dual and opposing roles of the unfolded protein response regulated by IRE1 $\alpha$ and XBP1 in proinsulin processing and insulin secretion. Proc Natl Acad Sci 108: 8885-8890.

Li Y, Ge M, Ciani L, Kuriakose G, Westover EJ, Dura M, Covey DF, Freed JH, Maxfield FR, Lytton J, et al. 2004. Enrichment of endoplasmic reticulum with cholesterol inhibits sarcoplasmic-endoplasmic reticulum calcium ATPase-2b activity in parallel with increased order of membrane lipids: Implications for depletion of endoplasmic reticulum calcium stores and apoptosis in cholesterol-loaded macrophages. J Biol Chem 279: $37030-$ 37039.

Lin JH, Zhang Y, Ron D, Walter P. 2009. Divergent effects of PERK and IRE1 signaling on cell viability. PLoS ONE 4: e4170.

Lipson KL, Fonseca SG, Ishigaki S, Nguyen LX, Foss E, Bortell R, Rossini AA, Urano F. 2006. Regulation of 
insulin biosynthesis in pancreatic $\beta$ cells by an endoplasmic reticulum-resident protein kinase IRE1. Cell Metab 4: $245-254$.

* Lord C, Ferro-Novick S, Miller EA. 2013. The highly conserved COPII coat complex sorts cargo from the endoplasmic reticulum and targets it to the Golgi. Cold Spring Harb Perspect Biol doi: 10.1101/cshperspect.a013367.

Lu PD, Harding HP, Ron D. 2004a. Translation re-initiation at alternative open reading frames regulates gene expression in an integrated stress response. J Cell Biol 167: $27-33$.

Lu PD, Jousse C, Marciniak SJ, Zhang Y, Novoa I, Scheuner D, Kaufman RJ, Ron D, Harding HP. 2004b. Cytoprotection by pre-emptive conditional phosphorylation of translation initiation factor 2. $E M B O J$ 23: 169-179.

Ma Y, Hendershot LM. 2003. Delineation of a negative feedback regulatory loop that controls protein translation during endoplasmic reticulum stress. J Biol Chem 278: 34864-34873.

* Mandon EC, Trueman SF, Gilmore R. 2013. Protein translocation across the rough endoplasmic reticulum. Cold Spring Harb Perspect Biol doi: 10.1011/cshperspect. a013342.

Marciniak SJ, Yun CY, Oyadomari S, Novoa I, Zhang Y, Jungreis R, Nagata K, Harding HP, Ron D. 2004. CHOP induces death by promoting protein synthesis and oxidation in the stressed endoplasmic reticulum. Genes Dev 18: $3066-3077$.

Maris M, Overbergh L, Gysemans C, Waget A, Cardozo AK, Verdrengh E, Cunha JP, Gotoh T, Cnop M, Eizirik DL, et al. 2012. Deletion of C/EBP homologous protein (Chop) in $\mathrm{C} 57 \mathrm{Bl} / 6$ mice dissociates obesity from insulin resistance. Diabetologia 55: 1167-1178.

McCullough KD, Martindale JL, Klotz LO, Aw TY Holbrook NJ. 2001. Gadd 153 sensitizes cells to endoplasmic reticulum stress by down-regulating Bcl2 and perturbing the cellular redox state. Mol Cell Biol 21: 12491259.

Murakami T, Saito A, Hino S, Kondo S, Kanemoto S, Chihara K, Sekiya H, Tsumagari K, Ochiai K, Yoshinaga $\mathrm{K}$, et al. 2009. Signalling mediated by the endoplasmic reticulum stress transducer OASIS is involved in bone formation. Nat Cell Biol 11: 1205-1211.

Novoa I, Zeng H, Harding H, Ron D. 2001. Feedback inhibition of the unfolded protein response by GADD34mediated dephosphorylation of eIF2a. J Cell Biol 153: 1011-1022.

Novoa I, Zhang Y, Zeng H, Jungreis R, Harding HP, Ron D. 2003. Stress-induced gene expression requires programmed recovery from translational repression. $E M B O$ J22: $1180-1187$.

Olzmann JA, Kopito RR, Christianson JC. 2013. The mammalian endoplasmic reticulum-associated degradation system. Cold Spring Harb Perspect Biol doi: 10.1101/ cshperspect.a013185.

Oyadomari S, Koizumi A, Takeda K, Gotoh T, Akira S, Araki E, Mori M. 2002. Targeted disruption of the Chop gene delays endoplasmic reticulum stress-mediated diabetes. J Clin Invest 109: 525-532.

Oyadomari S, Harding H, Zhang Y, Oyadomari M, Ron D. 2008. De-phosphorylation of translation initiation factor
$2 \alpha$ (eIF $2 \alpha)$ enhances glucose tolerance and attenuates hepato-steatosis in mice. Cell Metab 7: 520-532.

Ozcan U, Cao Q, Yilmaz E, Lee AH, Iwakoshi NN, Ozdelen E, Tuncman G, Gorgun C, Glimcher LH, Hotamisligil GS. 2004. Endoplasmic reticulum stress links obesity, insulin action, and type 2 diabetes. Science 306: $457-461$.

Ozcan U, Yilmaz E, Ozcan L, Furuhashi M, Vaillancourt E, Smith RO, Gorgun CZ, Hotamisligil GS. 2006. Chemical chaperones reduce ER stress and restore glucose homeostasis in a mouse model of type 2 diabetes. Science 313: 1137-1140.

Ozcan L, Ergin AS, Lu A, Chung J, Sarkar S, Nie D, Myers MG Jr, Ozcan U. 2009. Endoplasmic reticulum stress plays a central role in development of leptin resistance. Cell Metab 9: 35-51.

Promlek T, Ishiwata-Kimata Y, Shido M, Sakuramoto M, Kohno K, Kimata Y. 2011. Membrane aberrancy and unfolded proteins activate the endoplasmic reticulum stress sensor Ire1 in different ways. Mol Biol Cell 22: $3520-$ 3532.

Ron D, Habener JF. 1992. CHOP, a novel developmentally regulated nuclear protein that dimerizes with transcription factors $\mathrm{C} / \mathrm{EBP}$ and LAP and functions as a dominant negative inhibitor of gene transcription. Genes Dev 6: 439-453.

Scheuner D, Song B, McEwen E, Gillespie P, Saunders T, Bonner-Weir S, Kaufman RJ. 2001. Translational control is required for the unfolded protein response and in-vivo glucose homeostasis. Mol Cell 7: 1165-1176.

Shen X, Ellis RE, Lee K, Liu C-Y, Yang K, Solomon A, Yoshida H, Morimoto R, Kurnit DM, Mori K, et al. 2001. Complementary signaling pathways regulate the unfolded protein response and are required for C. elegans development. Cell 107: 893-903.

Shi Y, Vattem KM, Sood R, An J, Liang J, Stramm L, Wek RC. 1998. Identification and characterization of pancreatic eukaryotic initiation factor $2 \alpha$-subunit kinase, PEK, involved in translational control. Mol Cell Biol 18: 74997509.

Song B, Scheuner D, Ron D, Pennathur S, Kaufman RJ. 2008. Chop deletion reduces oxidative stress, improves $\beta$ cell function, and promotes cell survival in multiple mouse models of diabetes. J Clin Invest 118: 3378-3389.

Trusina A, Papa FR, Tang C. 2008. Rationalizing translation attenuation in the network architecture of the unfolded protein response. Proc Natl Acad Sci 105: 20280-20285.

Tsang KY, Chan D, Cheslett D, Chan WC, So CL, Melhado IG, Chan TW, Kwan KM, Hunziker EB, Yamada Y, et al. 2007. Surviving endoplasmic reticulum stress is coupled to altered chondrocyte differentiation and function. PLoS Biol 5: e44.

Tsaytler P, Harding HP, Ron D, Bertolotti A. 2011. Selective inhibition of a regulatory subunit of protein phosphatase 1 restores proteostasis. Science 332: 91-94.

Urano F, Wang X, Bertolotti A, Zhang Y, Chung P, Harding H, Ron D. 2000. Coupling of stress in the endoplasmic reticulum to activation of JNK protein kinases by transmembrane protein kinase IRE1. Science 287: $664-666$. 
Vattem KM, Wek RC. 2004. Reinitiation involving upstream ORFs regulates ATF4 mRNA translation in mammalian cells. Proc Natl Acad Sci 101: 11269-11274.

Virtue S, Vidal-Puig A. 2010. Adipose tissue expandability, lipotoxicity and the metabolic syndrome-An allostatic perspective. Biochim Biophys Acta 1801: 338-349.

Wang J, Takeuchi T, Tanaka S, Kubo SK, Kayo T, Lu D, Takata K, Koizumi A, Izumi T. 1999. A mutation in the insulin 2 gene induces diabetes with severe pancreatic $\beta$ cell dysfunction in the Mody mouse. J Clin Invest 103: 27-37.

Wang H, Kouri G, Wollheim CB. 2005. ER stress and SREBP- 1 activation are implicated in $\beta$-cell glucolipotoxicity. J Cell Sci 118: 3905-3915.

Wei MC, Zong WX, Cheng EH, Lindsten T, Panoutsakopoulou V, Ross AJ, Roth KA, MacGregor GR, Thompson CB, Korsmeyer SJ. 2001. Proapoptotic BAX and BAK: A requisite gateway to mitochondrial dysfunction and death. Science 292: 727-730.

Ye J, Rawson RB, Komuro R, Chen X, Dave UP, Prywes R, Brown MS, Goldstein JL. 2000. ER stress induces cleavage of membrane-bound ATF6 by the same proteases that process SREBPs. Mol Cell 6: 1355-1364.

Zhang P, McGrath B, Li S, Frank A, Zambito F, Reinert J, Gannon M, Ma K, McNaughton K, Cavener DR. 2002. The PERK eukaryotic initiation factor $2 \alpha$ kinase is required for the development of the skeletal system, post- natal growth, and the function and viability of the pancreas. Mol Cell Biol 22: 3864-3874.

Zhang X, Zhang G, Zhang H, Karin M, Bai H, Cai D. 2008. Hypothalamic IKK $\beta /$ NF- $\mathrm{KB}$ and ER stress link overnutrition to energy imbalance and obesity. Cell 135: 61-73.

Zhou D, Pallam LR, Jiang L, Narasimhan J, Staschke KA, Wek RC. 2008. Phosphorylation of eIF2 directs ATF5 translational control in response to diverse stress conditions. J Biol Chem 283: 7063-7073.

Zhou Y, Lee J, Reno CM, Sun C, Park SW, Chung J, Lee J, Fisher SJ, White MF, Biddinger SB, et al. 2011. Regulation of glucose homeostasis through a XBP-1-FoxO1 interaction. Nat Med 17: 356-365.

Zinszner H, Kuroda M, Wang X, Batchvarova N, Lightfoot RT, Remotti H, Stevens JL, Ron D. 1998. CHOP is implicated in programmed cell death in response to impaired function of the endoplasmic reticulum. Genes Dev 12: 982-995.

Zito E, Chin KT, Blais J, Harding HP, Ron D. 2010. ERO1ß, a pancreas-specific disulfide oxidase promotes insulin biogenesis and glucose homeostasis. J Cell Biol 188: $821-832$.

Zucker P, Logothetopoulos J. 1975. Persisting enhanced proinsulin-insulin and protein biosynthesis $\left({ }^{3} \mathrm{H}\right.$-leucine incorporation) by pancreatic islets of the rat after glucose exposure. Diabetes 24: 194-200. 


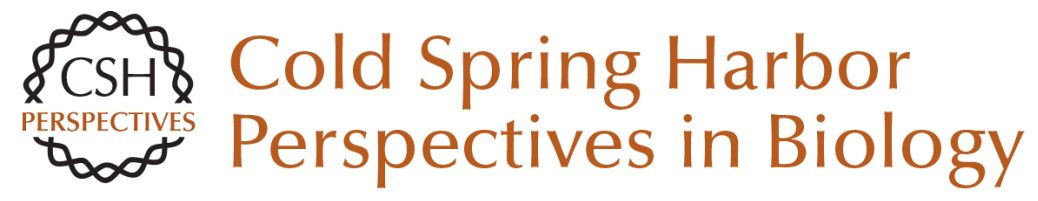

\section{Protein-Folding Homeostasis in the Endoplasmic Reticulum and Nutritional Regulation}

David Ron and Heather P. Harding

Cold Spring Harb Perspect Biol 2012; doi: 10.1101/cshperspect.a013177

Subject Collection The Endoplasmic Reticulum

Sorting and Export of Proteins at the Endoplasmic

Reticulum Ishier Raote, Sonashree Saxena and Vivek Malhotra

Endoplasmic Reticulum Membrane Contact Sites, Lipid Transport, and Neurodegeneration Andrés Guillén-Samander and Pietro De Camilli

AMPylation and Endoplasmic Reticulum Protein Folding Homeostasis Luke A. Perera and David Ron

The Endoplasmic Reticulum and the Fidelity of Nascent Protein Localization

Michael J. McKenna and Sichen Shao

Endoplasmic Reticulum Architecture and Inter-Organelle Communication in Metabolic Health and Disease

Ana Paula Arruda and Günes Parlakgül

Regulation and Functions of the ER-Associated Nrf1 Transcription Factor

Gary Ruvkun and Nicolas Lehrbach

Mechanism of Protein Translocation by the Sec61 Translocon Complex

Samuel Itskanov and Eunyong Park
Glycerolipid Synthesis and Lipid Droplet

Formation in the Endoplasmic Reticulum Robert V. Farese, Jr. and Tobias C. Walther

The Biogenesis of Multipass Membrane Proteins Luka Smalinskaite and Ramanujan S. Hegde

A TAle of Two Pathways: Tail-Anchored Protein Insertion at the Endoplasmic Reticulum Alina Guna, Masami Hazu, Giovani Pinton Tomaleri, et al.

Cholesterol Transport to the Endoplasmic Reticulum John P. Kennelly and Peter Tontonoz

The Role of the Rhomboid Superfamily in ER Protein Quality Control: From Mechanisms and Functions to Diseases

Satarupa Bhaduri, Nicola A. Scott and Sonya E. Neal

ER-Phagy: Quality and Quantity Control of the

Endoplasmic Reticulum by Autophagy Haruka Chino and Noboru Mizushima

Structure and Function of the Nuclear Pore

Complex

Stefan Petrovic, George W. Mobbs, Christopher J. Bley, et al.

For additional articles in this collection, see http://cshperspectives.cshlp.org/cgi/collection/

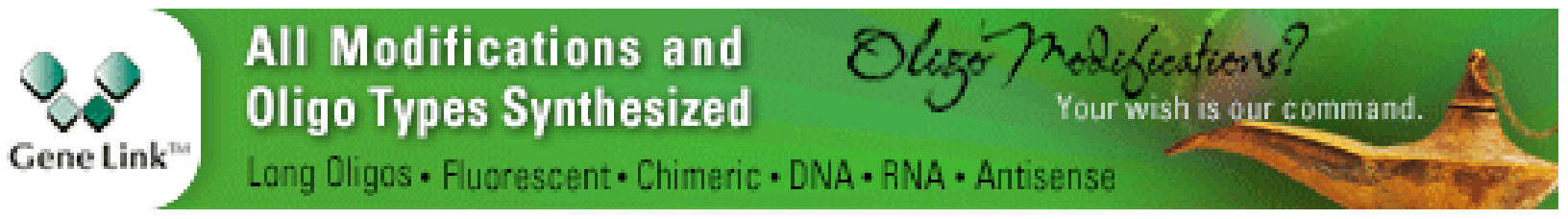




\section{Evolutionary Aspects of the Unfolded Protein Response \\ Kazutoshi Mori}

Post-Translational Regulation of HMG CoA Reductase

Youngah Jo and Russell A. DeBose-Boyd

For additional articles in this collection, see http://cshperspectives.cshlp.org/cgi/collection/

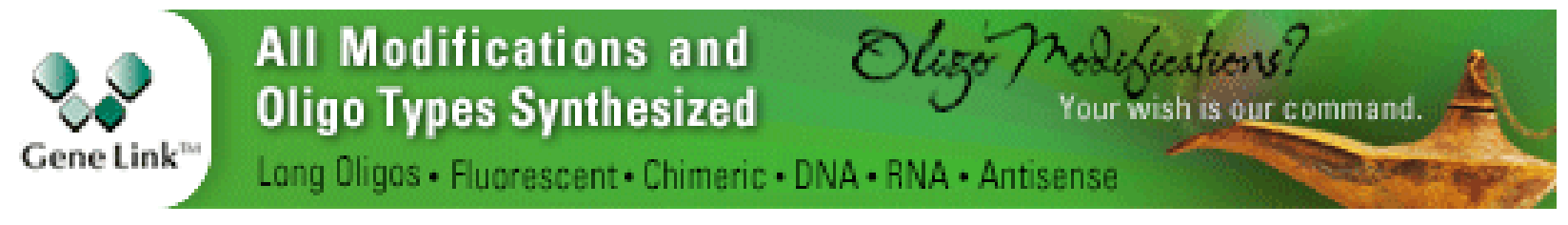

Copyright @ 2012 Cold Spring Harbor Laboratory Press; all rights reserved 